\title{
Estudo morfológico da sínfise púbica de ratos e camundongos durante a gravidez
}

\author{
Morphological study of rats and mice pubic symphysis during pregnancy
}

\author{
Flávia da Ré GUERRA'; Wagner Costa ROSSI JUNIOR²; Alessandra ESTEVES²; Valdemar Antônio \\ PAFFARO JUNIOR ${ }^{1}$
}

${ }^{1}$ Instituto de Ciências Biológicas da Universidade Federal de Alfenas, Alfenas - MG, Brasil

${ }^{2}$ Instituto de Ciências Biomédicas da Universidade Federal de Alfenas, Alfenas - MG, Brasil

\begin{abstract}
Resumo
O objetivo desse estudo foi avaliar as diferenças existentes na sínfise púbica de camundongos e ratos fêmeas, grávidas e não grávidas, descrevendo as alterações morfológicas ocorridas na articulação com a finalidade de entender os movimentos apresentados pela articulação ao longo da gestação. Para tal, as sínfises foram coletadas de camundongos fêmeas grávidas no $6^{\circ}, 12^{\circ} \mathrm{e} 18^{\circ}$ dias de gestação, e nas ratas com 18 dias de gestação. Foram fixadas em paraformoldeído e a seguir descalcificadas em solução de Morse. Na sequência, as peças foram incluídas em parafina. Cortes de 7 micrômetros foram realizados e corados em Picrosirius e Resorcina-Fucsina. A coloração com Picrosirius evidenciou em camundongos fêmeas virgens a presença de fibras grossas de colágeno diferente dos outros grupos de camundongos, os quais apresentaram fibras finas. A análise de fibras elásticas mostrou que, com o decorrer da gestação, estas aumentam em espessura e número. Em ratas com 18 dias de gestação foi observado o aparecimento de tecido conjuntivo fibroso no disco de cartilagem hialina, aumentando assim, o espaço inter-púbico e modificando a estrutura de sincondrose encontrada nos animais virgens. Observou-se também aumento no diâmetro e quantidade de fibras elásticas em relação às ratas virgens. Podemos concluir que a articulação de camundongos fêmeas grávidas passam por transformaçães estruturais qualitativas e quantitativas ao longo da gravidez. Em ratas prenhas, além do aumento de fibras elásticas e da distância entre os ossos do quadril, a articulação diferenciou-se pelo aparecimento de tecido conjuntivo fibroso para facilitar o parto.
\end{abstract}

Palavras-chave: Camundongos. Ratos. Fibras. Sínfise púbica. Gravidez.

\begin{abstract}
The objective of this study was to assess the existing differences in the pubic symphysis of female rats and mice, pregnant and non pregnant, describing the morphological alterations occurred in the joint and understanding the movements shown during pregnancy. The pubic symphysis were collected from female pregnant mice on the 6th, 12th and 18th days of pregnancy, and from rats with 18 days of pregnancy. They were fixed in paraformoldehyde and following decalcificated with Morse's solution. The samples were then, included in paraffin. Seven micrometers slices were made and stained with Picrosirius and Resorcin-Fuchsin. The Picrosirius staining had shown, in virgin female mice, the presence of thick collagen fibers different from the other groups of mice, which presented thin fibers. The analysis of elastic fibers showed that, with the progress of pregnancy there is an increase in their thickness and number. In rats with 18 days of pregnancy, an appearance of fibrous conjunctive tissue on the hyaline cartilage disc was observed, enlarging the inter-pubic space and modifying the synchondrosis structure found in the virgin animals. It was also observed an increase in diameter and amount of elastic fibers comparing to virgin rats. We conclude that the pregnant female mice's joint undergoes transformations in structure, quality and amount during the pregnancy. In pregnant rats, besides the increase of elastic fibers and the distance between the hip's bone, the joint had differred by the appearance of fibrous conjunctive tissue, thus making the birth easier.
\end{abstract}

Keywords: Mice. Rats. Fibers. Pubic symphysis. Pregnancy.

Rua Gabriel Monteiro da Silva, 700 - Alfenas MG, CEP: 37130-000

Telefone: (35) 3299-130

e-mail:wcrj@unifal-mg.edu.br

Recebido: 29/06/2009

Aprovado: 05/10/2011 


\section{Introdução}

Um parto satisfatório requer várias mudanças em toda a pelve feminina, em particular da sínfise púbica, a qual sofre algumas modificações estruturais ao longo da gravidez ${ }^{1}$.

Os ossos do quadril, direito e esquerdo, unem-se no plano mediano e formam a articulação anterior do cíngulo pélvico, a sínfise púbica. É uma união direta das faces sinfisiais pela fibrocartilagem do disco interpúbico. Cada uma dessas faces é revestida por uma fina lâmina de cartilagem hialina, unida firmemente ao osso por uma série de processos que se adaptam exatamente às depressões correspondentes da superfície óssea. Essas faces cartilagíneas opostas são ligadas por uma lâmina intermédia de fibrocartilagem, cuja espessura varia nos diferentes indivíduos ${ }^{2,3}$. Os ossos e ligamentos pélvicos tornam-se gradativamente mais móveis a partir da décima ou décima segunda semana de gestação, e estas alterações, que facilitam a passagem do feto no momento do parto, são decorrentes da ação de hormônios sexuais, destacando-se a relaxina e a progesterona ${ }^{4,5}$.

A sínfise púbica de ratos, porcos-da-índia e camundongos, machos e fêmeas, foi estudada por meio de microscopia de polarização. Em ratos adultos (machos e fêmeas) a sínfise púbica contém um centro de cartilagem hialina cercado por fibrocartilagem, sendo melhor classificada como uma sincondrose. Em fêmeas virgens de porcos-da-índia e camundongos, a sínfise púbica é formada por fibrocartilagem; constituindo-se em uma sínfise verdadeira. Camundongos machos tem uma estrutura da sínfise semelhante às camundongas virgens, enquanto porcos-da-índia machos (assim como os ratos) possuem uma juntura de cartilagem hialina ${ }^{6}$.

As modificações morfológicas e estruturais que sofre a pelve durante a gravidez têm como principal fator envolvido a ação de hormônios, destacando-se a relaxina e o estrógeno. A dilatação da sínfise púbica se inicia com uma degradação parcial da cartilagem hialina e ossos púbicos, associado ao crescimento do ligamento; isso permite o aumento do espaço de 0,2 $\mathrm{mm}$ para $0,6 \mathrm{~mm}$ entre os ossos do quadril, observado entre os dias 1 e 16 da gravidez ${ }^{7}$.

Outro fator observado ao longo da gravidez, foi uma intensa multiplicação celular em todo o ligamento púbico, promovendo assim uma dilatação deste ${ }^{8}$. A principal fonte de relaxina é o corpo lúteo na gravidez, mas também é encontrada em outros tecidos como testículos e ovários. A principal ação da relaxina ocorre na gravidez, direcionando a biosíntese de colágeno em órgãos alvo, facilitando a remodelagem de tecidos conjuntivos conectivos ${ }^{9,10}$.

Um estudo realizado com ratas não grávidas ovariectomizadas demonstrou que a administração de relaxina reduziu o teor total de colágeno, mas não teve efeito na solubilidade ou composição deste. Demonstrou ainda que a relaxina tem um potente efeito na quantidade de colágeno na sínfise púbica de ratas, sugerindo que as mudanças na matriz extracelular da sínfise púbica, induzidas pela relaxina, podem ser importantes nas modificações que esse tecido passa durante a gravidez $z^{11,12}$.

O relaxamento dos ligamentos pélvicos nas três primeiras semanas de gestação de porcos jovens está correlacionado com elevados níveis de relaxina, estrógeno e progesterona no sangue. Os estudos demonstram que a relaxina possui maior participação nas modificações do colo do útero e no relaxamento pélvico. A função do estrógeno e progesterona é pouco compreendida ${ }^{13}$.

Em camundongos, a sínfise púbica passa por transformações radicais durante a gravidez, começando com 0,2 $\mathrm{mm}$ de largura e atingindo cerca de $3 \mathrm{~mm}$ ao final da gravidez e, duas semanas após o parto, o espaço já está fechado ${ }^{14,15}$. Do décimo sexto dia em diante existe um acréscimo de mais de $2 \mathrm{~mm}$ nessa abertura, e é explicado, em certo grau, por mudanças significativas notadas em diferentes compartimentos da matriz extracelular. Entre essas mudanças está a degradação e 
remodelagem do colágeno ${ }^{5,16,17}$. Estas modificações do colágeno podem ser causadas pela relaxina que estimula a expressão da enzima colagenase $\mathrm{e}^{18,19}$.

Quando se consideram alterações do espectro e arquitetura das fibras da matriz extracelular que suportam as forças exercidas na junção púbica de camundongos, referência é normalmente feita na orientação paralela apresentada pelas fibras, especialmente na linha de tensão da articulação. Apenas em situações ocasionais, a resistência a essas forças é devida à perda do arranjo espiral das fibras colágenas ${ }^{20,21,22}$.

Dentre as alterações na matriz extracelular, ocorre degradação e remodelação do colágeno devido à ação de proteases, especialmente metaloproteases, e ao aumento de polissacarídeos hidratados, permitindo assim a flexibilidade do tecido ${ }^{23}$.

Estudos utilizando a relaxina em roedores machos e fêmeas não grávidas, revelaram inúmeras ações terapêuticas em tecidos não relacionados diretamente com a reprodução animal. A relaxina é importante na redução de fibrose do coração, pulmão, fígado, apresentando também ação vasodilatadora e diminuindo a ocorrência de isquemia. O conhecimento das ações fisiológicas e terapêuticas da relaxina relacionado com a recente identificação dos seus receptores celulares sustentará os inúmeros estudos relacionados com este polipeptídeo, especialmente os da indústria farmacêutica ${ }^{24}$.

Em virtude de todas essas modificações que ocorrem na sínfise púbica, ratos e camundongos são modelos clássicos para se avaliar o tecido conectivo entre os ossos púbicos, sendo possível a avaliação do sistema de fibras colágenas e elásticas existentes e que participam na fisiologia da articulação, seja na gravidez ou não.

O objetivo desse estudo foi avaliar as diferenças existentes na sínfise púbica de camundongos e ratos fêmeas, em diferentes estágios de gestação e não grávidas, descrevendo as alterações morfológicas ocorridas na articulação.

\section{Material e Método}

Foram utilizados 24 camundongos Swiss e 12 ratos Wistar, ambos do sexo feminino do Biotério Central da Unifal-MG e de acordo com os princípios éticos de utilização animal da Comissão de Ética da Unifal-MG, protocolo $\mathrm{n}^{\circ} 78 / 2006$. Os camundongos foram distribuídos em quatro grupos, contendo cada um seis animais, da seguinte maneira: Grupo 1 - animais virgens; Grupo 2 - animais com seis dias de gestação; Grupo 3 - animais com 12 dias de gestação; Grupo 4 - animais com 18 dias de gestação. As ratas foram distribuídas em dois grupos contendo cada um seis animais da seguinte maneira: Grupo 1 - animais virgens e Grupo 4 - animais com 18 dia de gestação.

Para o acasalamento, três fêmaeas foram colocadas com um macho por uma noite. Pela manhã, para verificar a ocorrência de acasalamento, observou-se nos camundongos fêmeas a existência de um "plug vaginal". E nos ratos fêmeas, por meio de esfregaço, a presença de espermatozoides na vagina. Confirmado o acasalamento, os animais foram separados em caixas e se tomou como o $1^{\circ}$ dia de gestação aquele em que foi verificado a ocorrência de acasalamento.

O procedimento cirúrgico para a retirada da sínfise púbica foi realizado com o animal devidamente anestesiado com cloridrato de quetamina (Ketalar ${ }^{2}$ [Pfizer Brasil] - $50 \mathrm{mg} / \mathrm{ml}$ ) e cloridrato de xilazina (Rompum $^{2}$ [Bayer Brasil] - 2 g/100ml), 1:1, na dose de $0,25 \mathrm{ml} / 100 \mathrm{~g}$ de peso. Após ser removida, a amostra foi fixada em paraformaldeído por 24 horas e, em seguida, transferida para álcool $70 \%$, onde permaneceu por mais 24 horas, e então se iniciou a descalcificação. As sínfises foram descalcificadas em solução de ácido fórmico e citrato de sódio $20 \%$ na proporção de $1: 1$ (solução de Morse), trocada diariamente, por aproximadamente 30 dias, até observar-se descalcificação, confirmada por reações bioquímicas que demostravam a ausência de matéria inorgânica. Após a descalcificação, as peças foram desidratadas e incluídas em 
blocos de parafina. Posteriormente foram realizados cortes transversais em relação ao longo eixo da articulação, semi-seriados, com sete micrômetros de espessura. Foram utilizados as colorações em Resorcina e fucsina, para visualização de fibras elásticas; e coloração em Picrosirius, para visualizar fibras colágenas. As lâminas foram analisadas por microscopia de luz convencional e de polarização para as lâminas coradas com Picrosirius.

Para a análise de morfometria, foi utilizado o programa Imaje J, onde foram tomadas medidas de comprimento e largura em três porções de cada sínfise púbica, uma no terço anterior, uma no terço médio e outra no terço posterior. A partir das três medidas tomadas foi realizado o teste T de Student, comparando-se todos os grupos com os animais virgens, optando-se por nível de significância de 5\% $(0,05)$.

\section{Resultados}

A microscopia de polarização mostrou os diferentes padrões estruturais do colágeno. Em camundongos fêmeas virgens, foi observada uma coloração vermelho-alaranjada que indica a presença de fibras mais espessas de colágeno, padrão este que pode ser visto em toda a articulação (Figura 1). Quando coradas com Resorcina-Fucsina, o padrão se mostra com fibras elásticas bem delgadas, provavelmente oxitalânicas e, aparentemente pouco numerosas (Figuras 2 e 3 ).

Em camundongos fêmeas com seis dias de gestação, observou-se um padrão muito semelhante ao das virgens com fibras colágenas mais espessas, indicando que não ocorreram alterações significativas. $\mathrm{O}$ mesmo pode ser observado quanto às fibras elásticas.

No grupo de camundongos fêmeas no $12^{\circ}$ dia de gestação, pode ser observada uma mudança no padrão de fibras colágenas onde estas se apresentam com coloração esverdeada, indicando fibras mais delgadas e mostrando um processo de remodelação para favorecer o parto. Os animais deste grupo apresentaram um aparente aumento do número de fibras

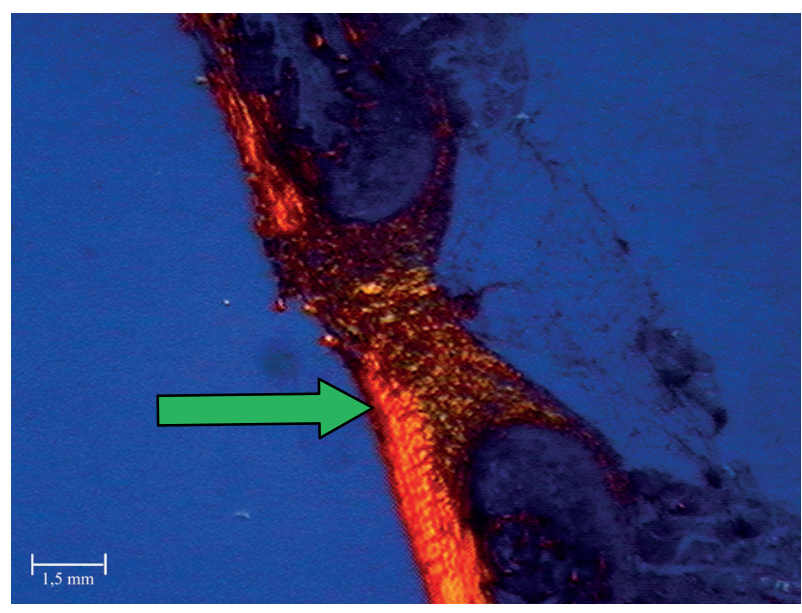

Figura 1 - Fotomicroscopia da sínfise púbica de camundonga com 18 dias de gestação, mostrando a estrutura de fibrocartilagem da sínfise (seta verde). Picrosirius sob luz polarizada

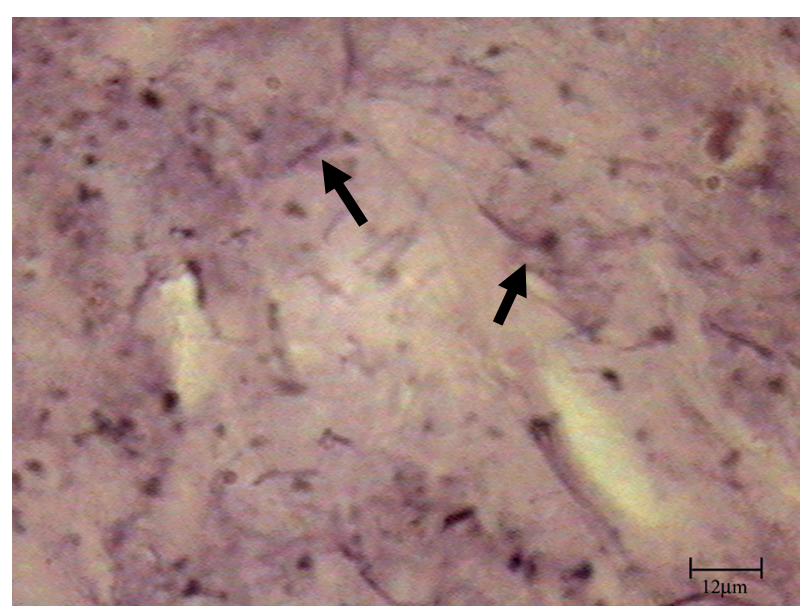

Figura 2 - Fotomicroscopia evidenciando fibras elásticas em corte de rata virgem, mostrando poucas fibras elásticas e, as existentes, são de pequeno calibre (setas). Resorcina

elásticas e de diferentes padrões, desde as fibras mais delgadas até as mais espessas.

Nos animais com 18 dias de gestação, sob luz polarizada, as fibras verdes, mais finas, puderam ser vistas com maior intensidade próximas à extremidade dos ossos (Figura 4). Observou-se também a existência de um maior número de fibras elásticas oxitalânicas em vários graus de espessura, destacando-se as de maior calibre.

Nas ratas virgens, o padrão foi diferente. Observou-se cartilagem hialina, diferente da fibrocartilagem encontrada nos camundongos fêmeas virgens, indi- 


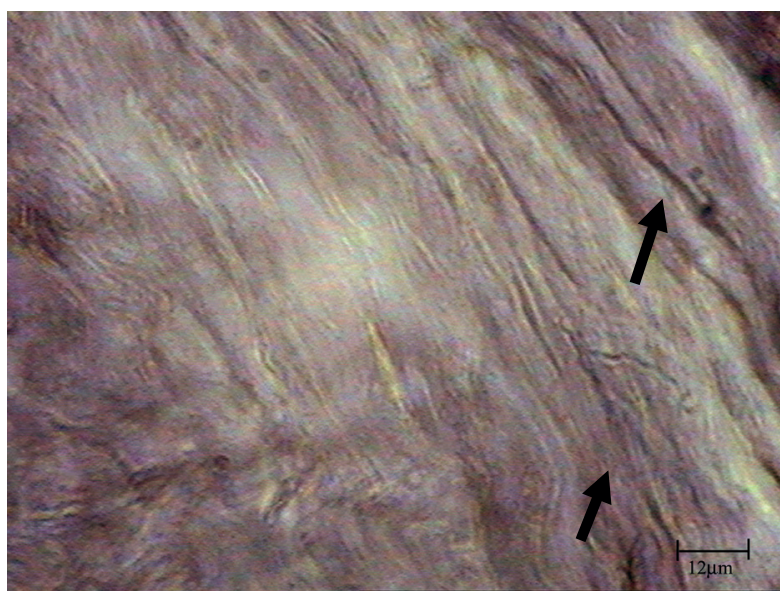

Figura 3 - Fotomicrografia mostrando fibras elásticas da sínfise púbica de uma rata virgem com poucas fibras e, as existentes, com pequeno calibre (setas). Resorcina

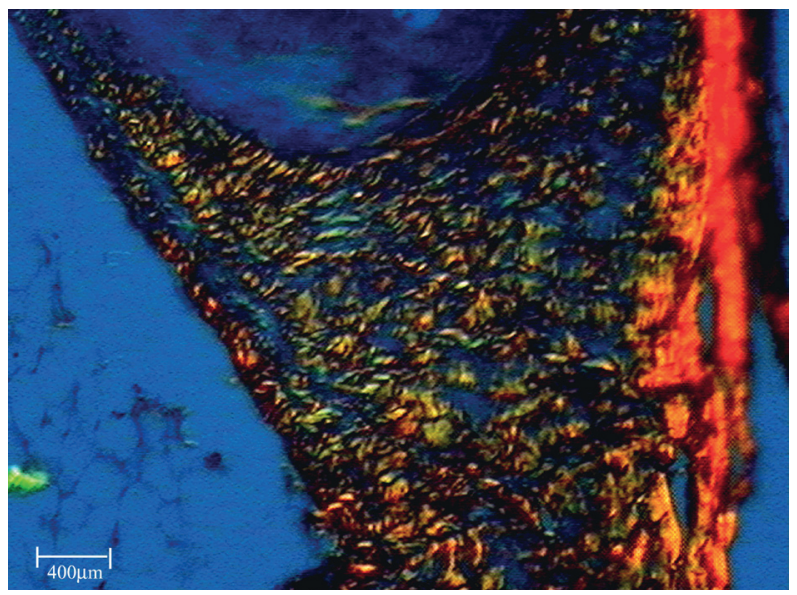

Figura 4 - Fotomicroscopia da sínfise púbica de camundongas com 18 dias de gestação, observando uma remodelagem do colágeno, evidenciando fibras mais finas (coradas em verde). Picrosirius sob luz polarizada

cando outro tipo de articulação. Quando feita a polarização, houve o predomínio de uma coloração esverdeada, indicando a presença de fibras colágenas mais delgadas, com menor diâmetro, ou outro tipo de colágeno predominante em cartilagem hialina (Figura 5).

Nos animais com 18 dias de gestação foi observado o aparecimento de tecido conjuntivo fibroso no disco de cartilagem hialina, dividindo-o em duas porções que se mantiveram fixas nas extremidades ósseas da articulação aumentando assim, o espaço inter-púbico (Figura 6). Observou-se também grande número de

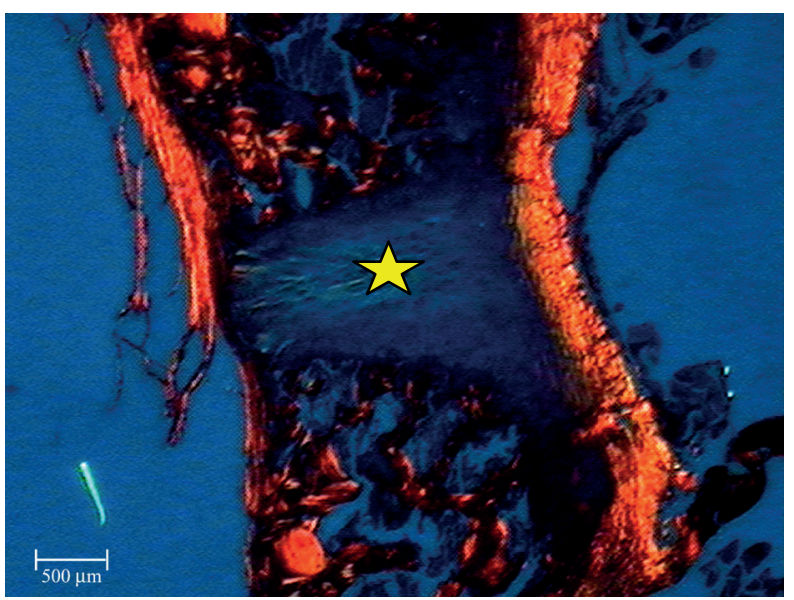

Figura 5 - Fotomicroscopia evidenciando a presença de fibras colágenas, observando-se uma sínfise púbica de rata virgem; a articulação se apresenta mais como uma sincondrose (estrela amarela)

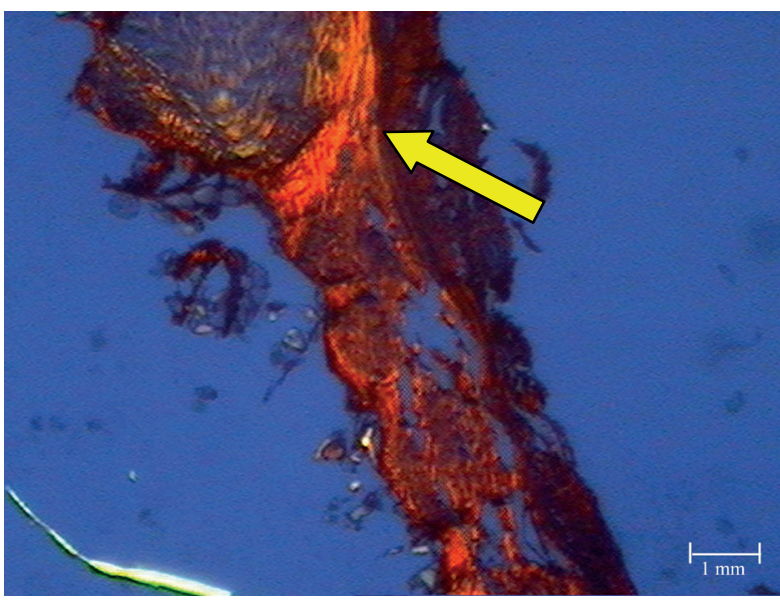

Figura 6 - Fotomicroscopia evidenciando a presença de fibras colágenas em sínfise púbica de rata com 18 dias de gestação, obeservando-se a deposição de fibrocartilagem entre os ossos púbicos (seta amarela). Picrosirius sob luz polarizada

fibras elásticas, com diferentes diâmetros e em maior quantidade em relação às ratas virgens (Figuras 7 e 8).

A análise morfométrica demonstrou que ao longo de toda a gestação de camundongos ocorreu um aumento adaptativo da distância entre os ossos púbicos. No grupo de camundongos virgens, o valor médio do comprimento da sínfise púbica foi de $218,49 \mu \mathrm{m}$. Naquelas com seis dias de gestação, a média de comprimento foi de $239,93 \mu \mathrm{m}$, mostrando um aumen- 


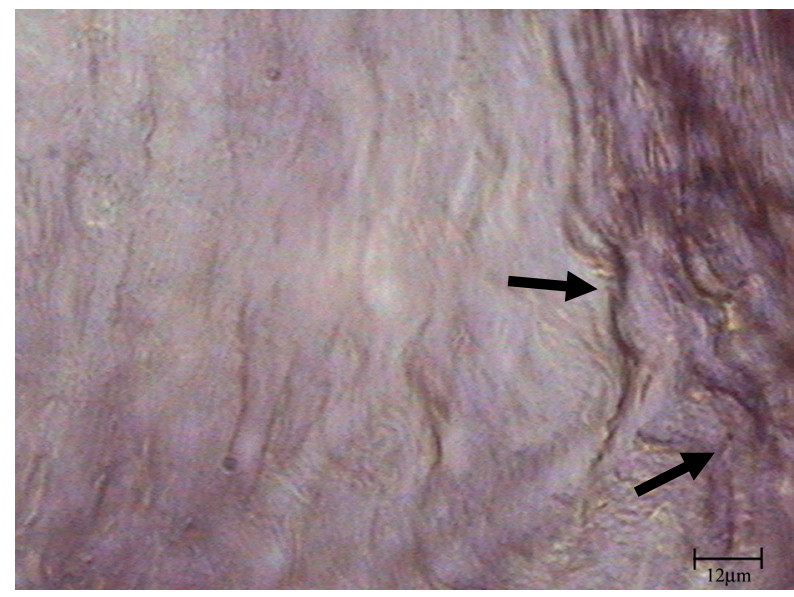

Figura 7 - Fotomicroscopia evidenciando fibras elásticas em um corte de sínfise púbica de rata com 18 dias de gestação, mostrando fibras de vários calibres, destacando-se as mais espessas (setas)

to estatisticamente significativo, quando comparado com o grupo anterior. Nas camundongos fêmeas com 12 dias de gestação, o valor médio foi de $685,79 \mu \mathrm{m}$, mostrando também uma significativa diferença na largura da articulação quando comparado com os animais virgens (Tabela 1). Aos 18 dias de gestação, a média do valor do comprimento foi de 741,61 $\mu \mathrm{m}$, demonstrando que houve um considerável aumento da sínfise púbica neste período de prenhez. Em ratas virgens, o valor da média do comprimento da articulação foi de $626,22 \mu \mathrm{m}$, enquanto que o valor da média do grupo de ratas com 18 dias de gestação, foi de $1301,51 \mu \mathrm{m}$ (Tabela 2). Estes valores são estatisticamente diferentes, indicando que houve um aumento do comprimento da articulação.

\section{Discussão}

O parto, em várias espécies, requer drásticas transformações na pelve materna, favorecendo assim a passagem do feto ${ }^{1,4} \mathrm{e}$, ao mesmo tempo, assegurando a integridade anatômica da pelve. Esse aumento da articulação pode ser explicado pela remodelagem de fibras de colágeno juntamente com a invasão do tecido por moléculas de água, que são atraídas pelas proteoglicanas e glicosaminoglicanas recentemente depositadas,

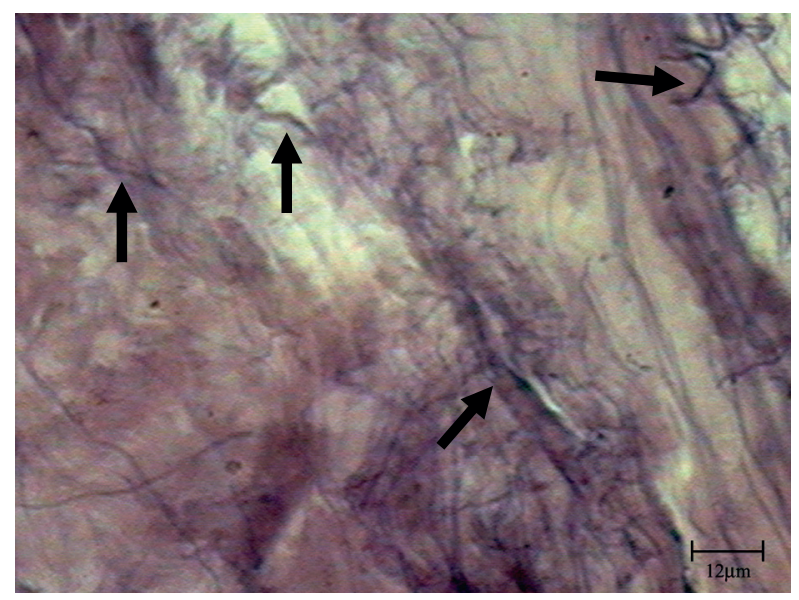

Figura 8 - Fotomicrografia mostrando fibras elásticas em um corte de sínfise púbica de rata com 18 dias de gestação, mostrando fibras de vários calibres, destacando-se as mais calibrosas (setas)

permitindo suficiente aumento do comprimento dessa articulação, de acordo com os estudos de Samuel, Coghlan e Bateman ${ }^{11}$ e Wahl, Blandau e Page ${ }^{18}$.

Observadas sob luz polarizada, as sínfises púbicas de camundongos com seis dias de gestação apresentaram uma estrutura muito semelhante aos animais virgens, com uma sínfise propriamente dita, podendo-se notar fibrocartilagem na articulação com uma coloração vermelho-alaranjada em toda a superfície analisada, indicando a presença de fibras mais espessas de colágeno, no caso colágeno do tipo I.

Já o grupo de camundongos fêmeas com 12 dias de gestação apresentou visíveis diferenças morfológicas com diferenças no padrão de coloração do colágeno, mostrando mais fibras finas (coradas em verde) que grossas (como na virgem), diferente do que foi observado por Pinheiro et al. ${ }^{23}$, o qual constataram que, aos 12 dias de gestação, podem ser observadas apenas pequenas diferenças no disco fibrocartilagíneo quando comparado com animais virgens. As diferenças notadas podem ser explicadas pela remodelagem das fibras de colágeno, que é um dos mecanismos responsáveis pelo preparo da articulação para o parto, tornando-se mais intenso à medida que evolui a gestação. 
Tabela 1 - Comparação entre as médias das larguras da sínfise púbica de camundongos fêmeas virgens (CV) com camundongos fêmeas de seis dias de gestação (C6) e também de camundongos fêmeas virgens comparadas com camundongos fêmeas de 12 dias de gestação (C12) - Alfenas - 2009

\begin{tabular}{cccc}
\hline Valores & CVxC6 & CVxC12 & Desvio Padrão \\
\hline Variância & & & \\
$\mathrm{Fe}$ & 1,79 & 4,82 & 2,14 \\
$\mathrm{~F} \alpha$ & 6,39 & 6,39 & 0,00 \\
$\mathrm{Te}$ & 3,2 & 26,74 & 16,59 \\
$\mathrm{~T} \alpha$ & 1,86 & 1,86 & 0,00 \\
\hline
\end{tabular}

Tabela 2 - Comparação entre as médias das larguras da sínfise púbica de ratas virgens (RV) e ratas com 18 dias de gestação (R18) - Alfenas - 2009

\begin{tabular}{cc}
\hline Valores & RVxR18 \\
\hline Variância & \\
$\mathrm{Fe}$ & 1,994 \\
$\mathrm{~F} \alpha$ & 9,604 \\
$\mathrm{Te}$ & 11,1972 \\
$\mathrm{~T} \alpha$ & 2,306 \\
\hline $\mathrm{DP}$ & 477,50 \\
\hline
\end{tabular}

DP - desvio padrão

A coloração em Picrosirius para visualizar fibras de colágeno baseia-se na utilização do Sirius Red, que é um corante vermelho escuro fortemente ácido de molécula alongada. Após a coloração com Sirius Red, a adição de grande quantidade de moléculas alongadas do corante, dispostas paralelamente às moléculas do colágeno que, além de se apresentarem fortemente birrefringentes, assumem cores variáveis, desde o verde até o vermelho. A intensidade da birrefringência e a cor apresentada dependem do tamanho e grau de compactação das estruturas contendo colágeno ${ }^{25}$.

A análise de fibras elásticas pela coloração com Resorcina-Fucsina evidenciou, em camundongos fêmeas virgens, a presença de fibras elásticas muito delgadas, sendo possivelmente fibras oxitalânicas, fato que também foi observado em todos os outros animais em período gestacional. Porém, a partir do $12^{\circ}$ dia de gestação, acompanhando a remodelagem e degradação do colágeno, foi observada a presença de fibras elásticas mais espessas, além das oxitalânicas, que se tornam mais frequentes e mais numerosas em animais com 18 dias, ocorrendo maior produção e deposição de elastina nas fibras oxitalânicas já presentes na fibrocartilagem, observada nos animais virgens. Esses achados estão de acordo com Moraes et al. ${ }^{5}$, que também observaram esta degradação e remodelagem do colágeno na sínfise púbica em camundongos fêmeas gestantes. Isto auxiliaria a estabilizar as forças atuantes da gravidez, permitindo maior mobilidade a articulação.

Quanto ao aumento da distância da articulação, observou-se diferenças estatísticas em todos os grupos quando comparados com o grupo de camundongos fêmeas virgens. Estas diferenças já são observadas nas fases iniciais da gestação, indicando que o processo de remodelação articular se dá de forma lenta, constante e gradativa. Estes resultados são discordantes daqueles obtidos por Pinheiro et al. ${ }^{23}$, os quais obtiveram diferenças somente após 12 dias de gestação. Os animais com 12 e 18 dias de gestação, apresentaram resultados mais significativos, o que indica que a expansão da articulação torna-se mais visível a partir do $12^{\circ}$ dia de gestação, aumentando de forma mais acelerada até o final da gravidez, o que também pôde ser confirmado por Pinheiro et al. ${ }^{23}$. 
Quanto aos grupos das ratas, observa-se claramente a modificação estrutural da articulação. Nas virgens, apresenta-se como uma sincondrose, fato que também foi verificado por Ortega et $\mathrm{al}^{6}{ }^{6}$, onde se pode observar um centro de cartilagem hialina, diferente da estrutura de sínfise como a encontrada nas camundongos fêmeas virgens. Este padrão modificou-se drasticamente nas ratas prenhas, ocorrendo o aparecimento de tecido conjuntivo fibroso no centro da cartilagem, dividido-a em duas porções limitadas às extremidades ósseas da articulação.

Estatisticamente, a sínfise ("sincondrose") de ratas com 18 dias de gravidez mostrou-se com maior comprimento que a de ratas virgens. Na coloração com Resorcina-Fucsina, as fibras elásticas, que se apresentaram mais grossas (fibras elásticas propriamente ditas) e em maior número, foram visualizadas nas ratas prenhas, indicando a remodelação da matriz extracelular, permitindo a deposição de elastina nas fibras finas, ou oxitalânicas. Estes achados indicam que houve uma diferenciação da

\section{Referências}

1. SHERWOOD, O. D. Relaxin - the physiology of reproduction. New York: Knobil, 1994. p. 861-1009.

2. TESTUT, G.; LATARGET, A. Anatomia humana. 9. ed. Barcelona: Salvat, 1985. p. 646-654.

3. GRAY, H. Anatomia. 29. ed. Philadelphia: Lea \& Febiger, 1977. p. 257-262.

4. GAMBLE, J. G.; SIMMONS, S. C.; FREEDMAN, M. The symphysis pubis. Anatomic and pathologic considerations. Clinical Orthopaedics and Related Research, v. 203, p. 261272, 1986.

5. MORAES, S. G.; CAMPOS PINHEIRO, M.; TOLEDO, O. M.; JOAZEIRO, P. P. Phenotypic modulation of fibroblastic cells in mice pubic symphysisduring pregnancy, partum and postpartum. Cell and Tissue Research, v. 315, n. 2, p. 223-231, 2004.

6. ORTEGA, H. H.; JOAZEIRO, P. P.; MUNOZ-DETORO, M. M.; LUQUE, E. H.; MONTES, G. Differential distribution of the fibres of the collagenous and elastic systems and of glycosaminoglycans in the rat pubic joint. Journal of Submicroscopic Cytology and Pathology, v. 33, n. 4, p. 463-472, 2001.

7. SHERWOOD, O. D.; DOWNING, S. J.; GUICOLAMM, M. L.; HWANG, J. J.; O’DAY-BOWMAN, M. B. FIELDS P. A. The physiological effects of relaxin during pregnancy: studies in rats and pigs. Oxford Reviews of Reproductive Biology, v. 15, p. 143-189, 1993. articulação durante a gestação, ao contrário do que propunha Ortega et al. ${ }^{6}$, que afirmam não existirem mudanças estruturais para o parto nesses animais.

Estes fatos reforçam a ideia de que animais de espécies diferentes, mas com semelhanças em vários aspectos, como ratos e camundongos apresentam, sim, semelhantes processos reprodutivos.

\section{Conclusão}

As sínfises púbicas de camundongos fêmeas grávidas passam por transformações estruturais qualitativas, tais como o aumento de fibras elásticas e remodelagem do colágeno por modificações da matriz extracelular; e quantitativas, como a expansão da sínfise púbica ao longo da gestação. Em ratas prenhas, além do aumento de fibras elásticas e da distância entre os ossos do quadril, a articulação mostrou diferenciar-se pelo aparecimento de tecido conjuntivo fibroso com a finalidade de promover um parto satisfatório.

8.LINCK, G.; OUDET, C.; PETROVIC, A. Multiplication of the different varieties of cells of the mouse pubic symphysis during growth and early gestation: radioautographic study with the use of tritiated thymidine. Bulletin de l'Association des Anatomistes, v. 59, n. 165, p. 467-478, 1975.

9.DA ROCHA, R. C.; CHOPARD, R. P. Nutrition pathways to the symphysis pubis. Journal of Anatomy, v. 204, n. 3, p. 209-215, 2004.

10. MACLENNAN, A. H. Relaxin--a review. Australian and New Zealand Journal of Obstetrics and Gynaecology, v. 21, n. 4, p. 195-202,1981.

11.SAMUEL, C. S.; COGHLAN, J. P.; BATEMAN, J. F. Effects of relaxin, pregnancy and parturition on collagen metabolism in the rat pubic symphysis. Journal of Endocrinology, v. 159, n. 1, p. 117-125, 1998.

12.STEINETZ, B. G.; BUTLER, M. C.; SAWYER, W. K.; O'BYRNE, E. M. Effects of relaxin on early pregnancy in rats. Experimental Biology and Medicine, v. 152, n. 3, p. 419-422, 1976.

13.WINN, R. J.; BAKER, M. D.; SHERWOOD, O. D. Individual and combined effects of relaxin, estrogen, and progesteronein ovariectomized gilts: effects on mammary development. Endocrinology, v. 135, n. 3, p. 1250-1255, 1994.

14.GARDNER, W. U. Sexual dimorphism of the pelvis of the mouse, the effect of estrogenic hormones upon the pelvis and upon the development of scrotal hernias. American Journal of Anatomy, v. 59, p. 459-483, 1936. 
15. HORN, E. H. Interpubic ligament regression in relaxin-treated virgin and primiparous, post-partum mice. Endocrinology, v. 67, p. 668-673, 1960.

16.UNEMORI, E. N.; BECK, L. S.; LEE, W. P.; XU, Y.; SIEGEL, M.; KELLER, G.; LIGGITT, H. D.; BAUER, E. A.; AMENTO, E. P. Human relaxin decreases collagen accumulation in vivo in two rodent models of fibrosis. The Journal of Investigative Dermatology, v. 101, p. 280-285, 1993.

17.ZHAO, L.; SAMUEL, C. S.; TREGEAR, G. W.; BECK, F.; WINTOUR, E. M. Collagen Studies in Late Pregnant Relaxin Null Mice. Biology of Reproduction, v. 63, p. 697-703, 2000.

18. WAHL, L. M.; BLANDAU, R. J.; PAGE, R. C. Effect of hormones on collagen metabolism and collagenase activity in the pubic symphysis ligament of the guinea pig. Endocrinology, v. 100, n. 2, p. 571-579, 1977.

19.UNEMORI, E. N.; AMENTO, E. P. Relaxin modulates synthesis and secretion of procollagenase and collagen by human dermal fibroblasts. Journal of Biology Chemistry, v. 265, p. 1681-1685, 1990.

20.CRELIN, E. S. The development of the bony pelvis and its changes during pregnancy and parturition. Transactions of the New York Academy of Sciences, v. 31, p. 1049-1059, 1969.

21.ZAMBRANO, N. Z.; MONTES, G. S.; SHIGIHARA, K. M.; SANCHEZ, E. M.; JUNQUEIRA, L. C. Collagen arrangement in cartilages. Acta Anatomic, v. 113, n. 1, p. 26-38, 1982.

22.PINHEIRO, M. C.; MORAES, S. G.; BATTLEHNER, C. N.; CALDINI, E. G.; TOLEDO, O. M.; JOAZEIRO P. P. Histochemical and ultrastructural study of collagen fibers in mouse pubic symphysis during late pregnancy. Micron, v. 35, n. 8, p. 685-693, 2004.

23. PINHEIRO, M. C.; JOAZEIRO, P. P.; MORA, O. A.; TOLEDO, O. M. Ultrastructural and immunohistochemical analysis of proteoglycans in mouse pubic symphysis. Cell Biology International, v. 27, n. 8, p. 647-655, 2003.

24.SHERWOOD, O. D. Relaxin's phisiological roles and other diverse actions. Arquivo Brasileiro de Endocrinologia e Metabologia, v. 25, n. 2, p. 205-234, 2004.

25.JUNQUEIRA, L. C. U; JUNQUEIRA, L. M. M. S. Técnicas básicas de citologia e histologia. São Paulo: Editora Santos, 1983. p. 72-73. Capítulo 3. 